\title{
ACCUSING HERESY IS A HERESY: How Heresy Became an Instrument in Political Sectarianism
}

\author{
Dina Yulianti \\ Universitas Padjadjaran Bandung, Indonesia \\ E-mail: dina14@unpad.ac.id \\ Otong Sulaeman \\ Sekolah Tinggi Filsafat Islam Sadra Jakarta, Indonesia \\ E-mail: osleman@yahoo.com \\ Muhammad Ilyas \\ Hauzah Siddiqatu Zahra Jakarta, Indonesia \\ E-mail: hedarali_a@yahoo.com
}

\begin{abstract}
The Islamic world in recent years, along with the phenomenon of the Arab Spring, witnesses the strengthening of sectarianism and takfirism which has even sparked the war in parts of the region. One of the main concepts used by the takfiris was puritanism, namely the obligation to dispose of other groups who are considered to have carried out heresy. This first, the determination of heresy article argues three main theses, by the takfiris is actually a heresy. The second thesis, heresy is not merely theological discourse but an instrument in the politics of sectarianism. The third one, heresy indictment is a postcolonial tool to weaken the Islamic World. This article uses the concept of politics of sectarianism, postcolonialism, and siyasi ijtima'i interpretation of Qur'an verses with maudhu'i method.
\end{abstract}

Keywords: Heresy; takfirism; politics of sectarianism; postcolonialism.

Article history: Received: 16 June 2020; Revised: 02 August 2020; Accapted: 24 August 2020; Available online: 01 September 2020.

\section{How to cite this article:}

Yulianti, Dina, Otong Sulaeman, and Muhammad Ilyas. "Accusing Heresy Is a Heresy: How Heresy Became an Instrument in Political Sectarianism". Religio: Jurnal Studi Agama-agama 10, no. 2 (2020): 189-209. https://doi.org/10.15642/religio.v10i2.1516 


\section{Introduction}

The emergence of armed militia groups in the Middle East during the Arab Spring era, especially in Iraq and Syria, simultaneously revived the 'anti-heretic' narratives, heresy accusations, and intolerant attitudes in the Muslim community. Some groups even use the narration as a justification for their extreme actions. The bombings of Sufi mosques or the tombs of 'saints' carried out by ISIS in Pakistan, Egypt, Syria and Iraq are examples of this extreme intolerance. The justification given by ISIS for the bombing of the saints' tombs is that the behavior of the pilgrims is heresy (bid'ab). ${ }^{1}$

Some classic research on heresy (from now on, in this paper, we will use the word bid'ah) is generally related to theological studies. One of them is the book entitled "Bid'ah in Religion: Itself, Cause, Classification, and Influence" written by Yusuf Al Qardhawi. Qardhawi states that Islam is very strict on bid'ah for three theological reasons. First, bid'ah principals have basically raised themselves up as the makers of the new law (syariah), and this means that bid'ah practitioners align themselves with God. Secondly, heretics see Islam as an incomplete teaching, and for that, they create something new in religion. Third, the practice of bid'ah has made religion difficult and at the same time eliminating its simplicity. This practice obviously contradicts the principle of "Islam is an easy religion".

Meanwhile, contemporary research related to bid'ah is generally divided into two, namely theological studies and case studies that link the concept of bid'ah with political views. Research on theological aspects includes, among others, Isa (2018), Kodir (2016), Sukron (2015). Jesus compared the concept of bid'ah from Imam Nawawi with the concept of bid'ah put forward by Sheikh Abdul Aziz Bin Baz, where Imam Nawawi acknowledged the existence of "heresy of hasanah" (good bid'ah) while Bin Baz looked at all heresies as heretical. ${ }^{3}$ Meanwhile Qodir discusses the history of the birth of the

\footnotetext{
1 Rukmini Callimachi, "To the World, They Are Muslims. To ISIS, Sufis Are Heretics" in https://www.nytimes.com/2017/11/25/world/middleeast/sufimuslims-isis-sinai.html / 25 November 2017/(accessed, September 1, 2019)

2 Yusuf Qardhawi, Bid ah dalam Agama: Hakikat, Sebab, Klasifikasi, dan Pengarubnya (Jakarta: Gema Insani Press, 2014), 3-4.

3 Mohamad Shafawi Bin Md Isa, Konsep Bid'ah Menurut Imam Nawawi Dan Syekh Abdul Aziz Bin Baz (Aceh: Thesis of Fakultas Syariah Dan Hukum Universitas Islam Negeri Ar-Raniry, 2018). https://repository.arraniry.ac.id/id/eprint/5665/1/Mohamad\%20Shafawi\%20Bin\%20Md\%20Isa.pdf
} 
concept of heresy in the first three centuries of Hijriyah. ${ }^{4}$ Sukron conducted a case study to find out the views of the Majelis Tarjih Alquran (the Assembly of Corroboration of Qur'an) about bid'ah. ${ }^{5}$

Related to political implications of bid'ah behavior, among others, researched by Sukring (2018) and Muliono et.al (2019). Sukring examined the political attitudes of the Khawarij groups who fought against Muslim leaders and fought against Muslims who they perceived as disobedient and concluded that this behavior was bid'ah. ${ }^{6}$ Research conducted by Muliono, Suwarko, and Ismail, found Salafi movements saw democracy as bid'ah, so they did not participate in elections, but they still accepted the leadership of the election results and did not carry out political movements to oppose the government. $^{\top}$

In this article, the authors explore the use of bid'ah narratives as political instruments and their implications at the global level. The remaining of this article will be divided into 4 parts, namely the definition and boundaries of bid'ah, accusing bid'ah is a bid'ah behavior, bid'ah as a sectarian political instrument, and bid'ah as an instrument of postcolonial politics. This research uses historical tracing (historical method) and apply arguments based on the Qur'an verses with the mandhu'i interpretation method of the type (lawn) siyasi ijtima'i. The authors use the concepts of sectarianism and postcolonialism in presenting arguments about heresy as a political instrument at the global level.

\section{Definition and Limitation of Bid'ah}

Bid'ah means to make new things that did not exist before. Associated with Islamic law (syariah), bid'ah means to create a new law that did not exist in the time of Prophet Muhammad SAW. Basically,

\footnotetext{
4 A Aceng Abdul Kodir, "Sejarah Bid'ah: Ashbab Al Hadith Dan Dominasi Wacana Islam Autentik Pada Tiga Abad Pertama Hijriyah", Wawasan: Jurnal Imiah Agama dan Sosial Budaya, Vol, 1, No. 2 (July 2016): 211-226.

5 Mokhamad Sukron, "Studi kasus: Memahami Bid'ah dalam Perspektif Majelis Tarjih Alquran (MTA)", Religió: Jurnal Studi Agama-agama, Vol. 5, No. 1 (Maret 2015): 94-113.

6 Sukring, "Ideologi, Keyakinan, Doktrin Dan Bid'ah Khawarij: Kajian Teologi Khawarij Zaman Modern “, Jurnal Theologia, Vol. 27, No. 2 (Desember 2016): 411430.

7 Slamet Muliono, Andi Suwarko, Zaky Ismail, "Gerakan Salafi Dan Deradikalisasi Islam Di Indonesia”, Religió: Jurnal Studi Agama-agama, Vol. 9, No. 2 (September 2019): 244-266.
} 
bid'ah is prohibited in Islam and this principle is axiomatic and is agreed upon by all schools of thought. However, the scholars and various schools of thought in Islam cannot easily agree on what behaviors belong to the bid'ah. This happens because bid'ah is a very general concept, namely all kinds of religious behavior that are considered new and not prescribed in the time of the Prophet Muhammad SAW.

Ja'far Subhani wrote that the effort to make appropriate limits related to the concept of bid'ah in its development was divided by several discussions, namely (a) the presence or absence of tolerance for the bid'ah behavior, (b) relations between bid'ab behavior with syariah behavior, and (c) the limitation of bid'ah on the syariah intervention only. ${ }^{8}$

\section{a. Tolerance for the Bid'ah Behavior}

In Islam, tolerance is an inseparable part in the implementation and enforcement of the law, including in punishing a behavior that is considered bid'ah. Some thinkers consider that there is no tolerance at all towards bid'ah. Others think that even though bid'ah is haram, it cannot be responded rigidly. This difference makes a bid'ah behavior has a gradation in the level of error, and this has an impact on the level of prohibition. ${ }^{9}$ In other words, there are some bid'ah behaviors that can be tolerated and some others that cannot be tolerated (haram). The presence or absence of tolerance is related with the difficulties on determining what behavior can be called as heretical heresy. From this point of view, the authors see that the bid'ab issue are not yet fully sound. What is considered as heretical behavior by a group of people may be regarded as mediocre behavior by other groups.

\section{b. Relationship of Bid'ah with Religious Behavior}

Heresy behavior is different from religious behavior. However, logically, two different things do not mean that they are in conflict. For example, prayer and charity are two different behaviors. Nonetheless, the two do not conflict, even support each other. This rules of logic creates differences of opinion regarding the definition of

\footnotetext{
8 Ja'far Subhani, Al-Bid'ah, Mafbumuba, Hadduba, Atsaruba (Qom: Mu`assasah AlImam Al-Shadiq, 1995), 14-15.

${ }_{9}$ Ibid., 24.
} 
heresy behavior. Some argue that bid'ah is different from religion, regardless of whether the difference creates a contradictory relationship between the two. Ibn Hazam, for example, states that everything that is new and not in the Qur'an or the Sunnah of the Prophet Muhammad is categorized as heresy behavior. Even so, Ibn Hazm makes an exception that the new behavior is not categorized as heresy if it has good intentions or it is a good behavior, or behavior that is basically categorized as mubah. ${ }^{10}$

Meanwhile, Imam Syafi'i, as quoted by Ibn Hajar, divides the new behavior (bid'ah) into two parts: the first one is despicable behavior, which is contrary to the Qur'an, Sunnah, ijma' or atsar. Imam Syafi'i called it bid'ah dhalalah. The second one is a new behavior that does not conflict with religious sources. Ibnul Atsir called it bid'ah budâ or bid'ah which contained guidance. An example of bid'ah hudâ is tarawih prayer, as Umar bin Khatab radhiyallah anbu said, "The best bid'ab is this, the tarawih prayer." 11

Tarawih prayer is recognized as a bid'ah, which means a sharia act that was not performed by Prophet Muhammad, but it is still considered a virtue, in the sense that it does not contradict the Qur'an and Sunnah and moreover, such behavior was exemplified by the Shababah (the companions of the Prophet). This opinion is based on the hadith Rasulullah SAW which ordered Muslims to not only follow the sunnah of the Prophet, but also the sunnah of Khulafa Al-Rashidin. Ibnul Athir in an-Nihayah asserted that tarawih prayer is a good deed because it was the sunnah of Umar bin Khathab radbiyallab anbu and he, as one of the Khulafa' Al-Rashidin, had the right to establish an act as the sunnab called "sunnatu as-shababiy" (the sunnab of the Companions). ${ }^{12}$

Differences of opinion regarding the presence or absence of good bid'ah, indicate that bid'ah does not have a solid definition. Those who are consistent with the opinion of Ibn Hazam will reject any new behavior in the name of Islamic teachings, when the new behavior was apparently never carried out in the time of the Prophet Muhammad. However, for those who believe in a good bid'ah, they certainly have different opinions and will show resistance to the bid'ah accusations made by other parties.

\footnotetext{
${ }^{10}$ Ibid, 25.

11 Ibid.

12 Ibid., 26.
} 


\section{c. Limitation of Bid'ah only in the Sharia Field}

Bid'ab is actually a term that is related to all parts of the teachings of Islam. However, in fact, the Prophet referred to a behavior as heresy if the behavior was related to sharia law issues. Thus, the scholars generally argue that behavior is called bid'ah if the behavior intervenes the established Sharia law. Ibn Hajar Al-Asqalani, for example, argues that bid'ab is all new behavior in the field of law (sharia). ${ }^{13}$

Some scholars believe that bid'ah is related to all fields of religion, not only related to sharia. Bid'ah can also include creeds and morals. Subhani quoted Muhaqiq Asytiyani's opinion in the book "Bahr Al-Fawaid" and Sayyid Al-Amin in the book "Kasyf Al-Irtiyab" related to the definition of bid'ah. They say that bid'ab is including non-religious behavior as a religious matter. For example, regarding something that is actually haram as halal; or forbidding something that is actually allowed (mubab); or obligating something that is actually sunnab. Bid'ah applies not only in terms of sharia law, but also in other religious fields, such as creed (aqidab). ${ }^{14}$

In Islamic teachings, every action must have a legal value, which is obligatory (wajib), sunnah, mubah, makruh, and haram. By referring to the opinion of Asytiyani and Al-Amin, bid'ah has the definition of 'acts to change the legal value of a behavior'. Examples of bid'ah in this category are celibacy of Christian priests (rabbaniyah) as mentioned in the Surah Al-Hadid verse 27. The Qur'an says that rabbaniyyah is not part of the sharia of Isa Al-Masih a.s., so it is a heresy behavior after his death. Rabbaniyyah was originally part of a good attitude of zubud. Righteous people at that time postponed marriage and stayed away from other worldly pleasures as a way of training themselves against lust. However, lately, they claimed that marriage is haram in religion. ${ }^{15}$ According to a hadith, Uthman ibn Mazh'un came to the Prophet one time and asked permission to do ikhsha' (castration). Rasulullah said, "Whoever does castration is not from our group. Surely ikhsha' for my people is fasting." In another

\footnotetext{
13 Ibnu Hajar Al-Asqalani, Fath Al-Bari, Syarh Al-Bukhari, Jilid V (Kairo: Mustafa AlBab Al-Habi, 1959), 156.

${ }^{14}$ Subhani, Al-Bid'ah, Mafbumuba, 29.

15 Mohsen Qara'ati, Tafsir-e Noor, Jilid 9 (Qom: Markaz-e Tahqiqat-e Noor, 1999), 490.
} 
narration, the issue of rabbaniyyah is mentioned. Rasulullah SAW said, "Tarahub for my people is sitting in the mosque waiting for prayer." 16

The prohibition of celibacy and castration as two example of heresy show that: first, when the bid'ab is done, there is a change in the legal value of a behavior by the heresy. Delaying marriage for a while because someone wants to concentrate on worship is a sunnah behavior. However, in its development, the behavior was changed to mandatory. That is, celibate actors have changed a sunnah behavior to become mandatory. Second, the object of bid'ah is not only limited by sharia. In religion, delaying marriage and being zubud are in the domain of morals, not sharia.

Subhani also stated that there were quite a number of ulama who argued that bid'ab was not only limited to the sharia field. They argue that there is no statement from the Prophet Muhammad that shows the limitation of bid'ab only in the field of sharia. In conclusion, bid'ah applies to all kinds of religious behavior. ${ }^{17}$ As a result of difference of opinion among scholars regarding this problem, it is difficult for Muslims to find agreement regarding the definition of bid'ah. Some argue that a new behavior is only categorized as heresy only if it intervenes or changes the sharia. While another group stated that bid'ab was related to all aspects of religion. The impact of the discrepancy is the emergence of three thesis that the authors will explain in the following sections.

\section{Accusing Bid'ah is a Bid'ah Behavior}

The first thesis is that someone who inconsiderably accuses another party as bid'ah doer is actually doing bid'ah. To prove this thesis, the authors will use the interpretation of some Qur'anic verses related to the prohibition of heresy and the interdiction (baram) to accuse fellow Muslims baselessly. The authors will use the thematic interpretation method (mawdhu'), which is interpreting a number of Qur'anic verses that have the same theme.

In the Surah Al-An'am verse 159, Allah SW'T condemns those who divide Islam and have a tendency to become sects. In that verse, Allah ordered the Rasulullah SAW to disassociate from such people, and surrender their fate in the hereafter to Allah who will punish

16 Abu Ishaq Ibrahim Al-Syathibi, Al-I'tisham, (Beirut: Dar Al-Kutub Al-'Ilmiyah, 2012), 325.

17 Subhani, Al-Bid'ah, Mafbumuba, 30. 
them. Qara'ati in his commentary (tafsir) wrotes that creating divisions in religion is a form of heresy because it arises from the behavior of interpreting religion on the basis of self-interest. Moreover, in Surah Al-Baqarah verse 79 , they are criticized as wretched people because they like to write something that comes from their own thoughts, then they claim that what they wrote comes from God. ${ }^{18}$

The phenomenon of 'creating divisions' by using bid'ah verdict and claiming that the verdict comes from God is mostly done by Wahhabi groups. They, by referring to the opinion of Ibn Taymiyyah, tend to sentence all the groups outside them as heretics. Among other things, according to Wahabi teachings, all philosophers such as AlFarabi and Ibn Sina were deviant and misleading heretics. Wahabis also believe that the Shia, Mu'tazilah, Ash'ariah, and Khawarij are misguided theological school and create bid'ah in the midst of the Ummah. ${ }^{19}$

The situation of accusing each other as heretics in the midst of Muslims is a dangerous phenomenon. Throwing baseless accusations at fellow Muslims is a behavior that has been severely criticized by the Qur'an. In surah Al-Ahzab verse 58 Allah says, "And those who harm believing men and believing women for [something] other than what they have earned have certainly born upon themselves a slander and manifest sin." 20 Strong condemnation to people who make accusations baselessly is also stated in Surah Al-Nisa verse 112, "But whoever earns an offense or a sin and then blames it on an innocent [person] has taken upon himself a slander and manifest sin." 21

This verse speaks of people who make mistakes and sins. In the previous verse (verse 110), Allah stated that he would forgive the sins of those who realized their mistakes. In the next verse (verse 111), Allah states that the sinful behavior will ultimately have a bad effect on the culprit. That is, if someone commits a sin, and he is reluctant to repent, he will get a bad effect on himself. Then, in verse 112, it is stated that there are sinners who blame their sins on others. It is these people who are declared liars and will suffer painful punishment. AlNisa verse 112 speaks about the very bad habit of accusing others of being sinners. When we contemplate the order of the verses, we will

\footnotetext{
18 Qara'ati, Tafsir-e Noor, 591.

${ }^{19}$ Subhani, Al-Bid'ah, Mafbumuba, 119.

20 Translation of Qur'an verses, https://quran.com

${ }^{21}$ Ibid.
} 
find that "accusing" is the culmination of the ugliness of sin. If someone commits a sin, God calls him a wrongdoer and he will pay a cost of it. However, if his sinful behavior is accompanied by accusations to other parties, God denounces him as the perpetrator of a great sin that will suffer painful torture. From this verse it can also be concluded that the person who likes to make accusations of sin to others is usually the sinner himself.

This model of comprehension can be applied to the issue of heresy. As discussed above, bid'ah becomes haram because this behavior changes the legal value (sharia law) of a matter/issue. With such perspective, forbiding something that is actually not haram can be called a bid'ah. Therefore, the behavior of accusing another party as a heresy baselessly, is precisely the behavior of the heresy itself. For example, accusing the celebration of the birth of the Prophet (maulid Nabi) as a heresy is parallel to sentence maulid as a haram ritual. Meanwhile, forbidding something that is actually not haram is a heresy. Thus, in this case, accusing bid'ah is bid'ab itself.

\section{Bid'ah as Instrument of Sectarian Politics}

According to the Meriam-Webster dictionary, sectarians is "an adherent of a sect" or "a narrow or bigoted person". In many cases, sectarian identities are politicized. Hashemi wrote that a politicizing of sectarian identities happens when some religious groups take joint action based on the differences between beliefs or schools. In other words, normally differences in beliefs are generally accepted by the community, but when there is a joint action carried out by groups with certain identities (beliefs) towards other groups, that's when sectarianism becomes a political instrument. Hashemi assessed that the factors causing sectarian conflict were not differences of belief but politics. ${ }^{22}$

Sectarian conflicts in the Middle East since the Arab Spring generally occur between Sunni and Shia groups, whereas previously the two communities could coexist with one another. The majority of Muslims in the world are Sunni (85-90\%), while significant Shiite populations gather in several countries such as Iran, Iraq, Bahrain,

${ }^{22}$ Nader Hashemi, "Toward a Political Theory of Sectarianism in the Middle East: The Salience of Authoritarianism over Theology," in https://www.mei.edu/publications/toward-political-theory-sectarianism-middleeast-salience-authoritarianism-over\#_ftn7 /27 October 2015 (accessed, September 1, 2019). 
Lebanon, Afghanistan, Kuwait, Yemen, Saudi Arabia, Pakistan and Syria. According to Hashemi ${ }^{23}$, Sunni-Shia sectarian conflicts occur in countries that have an authoritarian political system and this is the main factor in the sectarian politics. Along with the so called 'the wave of Arab Spring' where the people of various Middle Eastern countries rose to protest against their governments, a number of these authoritarian administrations tried to control their citizens by manipulating different beliefs or identities among citizens, politicizing them, and using them to divide their citizens.

In the 1960s to $1970 \mathrm{~s}$, in a number of Muslim countries, some political opposition groups moved based on the ideas of socialism or communism. A number of leaders in the Middle East tried to silence the opposition movement by utilizing political Islamist groups that labeled 'heretics' or 'infidels' on the ideas shared by the opposition groups. Among the examples of this case was Egyptian President Anwar Sadat who in the 1970s released Muslim Brotherhood members from prison to help him fight the left opposition. ${ }^{24}$ In another case, the formation of Yemeni Arab Republic in 1990 had united two major political factions, the Ali Abdullah Saleh (Zaidiyah Shiite) camp and the Ali Salim Beidh (socialist) camp. To subdue the socialists, Saleh cooperated with the Muslim Brotherhood elements who founded the Islah Party on September 13, 1993. According to its founder, Sheikh Abdullah bin Hasan al-Ahmar, the main objective of the establishment of this party was to fight the socialists. Saleh had to use the hands of the Islah Party, because his own party (the General People's Congress) was bound by a unification agreement with the Socialist Party. ${ }^{25}$ During the Arab Spring there was a shift in strategy carried out by authoritarian regimes, namely by accusing political opponents of being heretics or bid'ah doers, as happened in Saudi Arabia, Yemen, and Bahrain. The community which is considered as bid'ah doers, in cases of the Arab Spring era, is the Shia community.

\footnotetext{
23 Ibid.

24 Ibid.

25 Farea Al-Muslimi, "Yemen's Brotherhood: Early Losses and an Unknown Future" in https://www.al-monitor.com/pulse/fr/originals/2013/09/yemenbrotherhood-losses-unknown-future.html /25 September 2013 (accessed, September 2, 2019)
} 
$\mathrm{Abdo}^{26}$ assessed that the main factor in the Middle East conflict is sectarianism, because Middle Eastern society has doctrinal differences that have not been resolved since centuries ago. The main point of the debate is who are the true believer and who are the nonbeliever. Abdo cites a survey conducted by Pew which found that many Muslims do not believe that the practices of the Shiites, such as pilgrimage to the holy tombs, and offering prayers through the intercession (tawasul) of religious figures who have died are true Islamic traditions.

Instead, Hurd ${ }^{27}$ argues - by examining the case of Bahrain and Israel - that sectarianism is used as a political instrument to maintain the status quo of the regime. According to Hurd, in the case of Bahrain's demonstrations, there was a significant difference between the sectarian narratives brought by the regime and the non-sectarian agenda of Bahrain's democratic opposition groups. Identifying these differences will lead us to conclude that the demonstrations at Bahrain were not sectarian acts as alleged by the Al-Khalifa regime. On the contrary, it is the Bahraini regime who is conducting political sectarianism.

Bahraini Authority has been disseminated sectarian narratives since the beginning of pro-democracy demonstrations in the country, namely on February 14, 2011. One of the narratives delivered by the Bahraini government is that opposition groups are having Shiite political agenda, namely to overthrow the $\mathrm{Al}$ Khalifa regime to establish a theocratic government co-opted by Iran. According to Hurd, the Al Khalifa regime has sought to use the perception of sectarian differences for political purposes in order to maintain its power despite insufficient evidence that the Bahraini opposition received instructions from Tehran. ${ }^{28}$

However, because most opposition groups in Bahrain come from the Shiite community, including the Al-Wefaq National Islamic Society Party, which is a Bahraini Shiite political party, the sectarian narrative of the regime achieved success, in the sense of becoming a mainstream narrative that was accepted by public opinion in domestic or foreign. As a result, anti-human rights actions by the Bahraini

\footnotetext{
${ }^{26}$ Geneive Abdo, The New Sectarianism: The Arab Uprisings and The Rebirth of The Shi' aSunni Divide (New York: Oxford University Press, 2017), 8-9.

${ }^{27}$ Elizabeth Shakman Hurd. "Politics of Sectarianism: Rethinking Religion and Politics in The Middle East,” Middle East Law and Governance. Vol. 7 (2015), 61-75.

${ }^{28}$ Ibid., 66.
} 
government did not get significant protest from public opinion. Bahraini Watch activist, Ala'a Shehabi wrote:

For three years, the regime has destroyed Shiite mosques, carried out sectarian profiling, and "cleansed" state institutions in a crackdown during which up to 15,000 people have been arrested; around 3,000 remain in prison. The government's sectarian narrative- that the Sunni regime and its loyalists are threatened by the Shiites, who make up two-thirds of the Muslim population-is the paradigm that has been used to frame the Bahraini pro-democracy uprising right from the start. The opposition does include Shiites, who are justly aggrieved by decades of exclusion, but also many others whose longstanding demand has been for a constitutional monarchy and human and civil rights. ${ }^{29}$

In other words, the Shia were part of the opposition but not the only one: many other factions joined in the pro-democracy action against the monarchy of $\mathrm{Al} \mathrm{Khalifa,} \mathrm{which} \mathrm{demanded} \mathrm{the} \mathrm{adoption} \mathrm{of}$ a constitutional monarchy and respect for human rights.

On the contrary, in the Syrian case, it was the opposition groups who use sectarian narratives as justification for the armed actions (including bombings) they carry out to overthrow the government of Bashar Assad who had been elected through a democratic process (election). Abdo ${ }^{30}$ wrote, one of the main supporters of the armed militia movement in Syria is a Saudi cleric named Mohammad Al Arefe who is very popular in the Middle East, among others seen from his Twitter account followers who reached 14 million (as of February 2016). Arefe is very active in calling for young people in the Middle East to join the 'jihad' in Syria.

Abdo interviewed Arefe on May 15, 2011 and he said:

Shi'ism is a heresy. It did not exist at the time of the Prophet or [the first and third Caliphs] Abu Bakr or Uthman. They have an issue with making Ali (peace be upon him) greater than he is. Then they started with other heretical things like building shrines on graves, praying to others than God, claiming that Ali knows the unknown and that he brought the dead back to life. ${ }^{31}$

\footnotetext{
29 Ala'a Shehabi. "Why Is Bahrain Outsourcing Extremism?" in https:/ / foreignpolicy.com/2014/10/29/why-is-bahrain-outsourcingextremism//29 October 2014/ (accessed, September 5, 2019).

30 Abdo, The New Sectarianism, 71.

31 Ibid., 74.
} 
In this statement it appears that Arefe considered Shia community as heretic group and at the same time he pushed for the overthrow of the Assad regime who has been accused as Shia by his opponent. Thus, there is a 'joint action' from one group against another based on differences in belief.

Hurd $^{32}$ and Hashemi ${ }^{33}$ both conclude that analyzing conflicts in the Middle East merely from a sectarian aspect is not sufficient to provide an explanation of the conflict; it is even reducing the complexity of opposition groups and their demands into a single narrative voiced by authoritarian regimes. Hurd suggested that academics approach this issue with the perspective of 'mobilizing religion in politics' and digging deeper into who made the mobilization, for the sake of who, and what is its impact. Meanwhile, Hashemi stated that the complex reality of Middle East politics cannot be reduced to the alleged existence of a lasting Sunni-Shiite dispute because the Middle East's instability was rooted in the development crisis (both political and economic) experienced by the region since the era of independence and was greatly influenced by policies and foreign intervention.

Thus, the authors conclude that accusations of heresy are used as instruments in the politics of sectarianism. In the next part, the writer will argue that the Western power has a big role in shaping sectarian identities in the Middle East, especially in relation to mainstreaming narratives of bid'ah accusations which then serve as justifications for acts of terror for gaining power.

\section{Bid'ah as Political Instrument of Postcolonial Western for Control Islamic World}

The concept of post-colonialism is a thought or idea related to the impact of colonization on culture and society. In the late 1970s this concept was used by literary critics to discuss various effects of colonial culture in literary works, but later it is used in the study of history, politics, sociology, and economics because all of these disciplines were deeply involved with the impact of European

\footnotetext{
32 Hurd, "Politics of Sectarianism...", 66.

33 Hashemi, "Toward a Political Theory of Sectarianism."
} 
imperialism on the world. ${ }^{34}$ Chowdhry and Nair by citing Shome $(1998)^{35}$ wrote that the study of postcolonialism allows us to understand the complex shifts caused by decolonization. Thus, according to Chowdhry and Nair, the term 'postcolonial' does not mark the end of colonialism but rather reflects the continuation of colonial practices in their former colonies. Postcolonial studies provide a deeper understanding of how imperialist (Western, European) forces are involved in the construction of power relations, hierarchies, and domination in former colonies.

Among the thinkers who laid the foundations of postcolonialism studies was Edward Said who through his work "Orientalism" explained how the production of knowledge and power was related to the will of the West to continue to maintain its dominance in ex-colonial countries. Said criticized Western academics and cultural figures who produce knowledge about the East by positioning the West as a superior party, while the East are backward nations. ${ }^{36}$

By using the concept of postcolonialism, the authors traces the history of the birth of Islamic knowledge that emphasizes purification that has political implications, namely providing justification for acts of violence against those who are judged to commit heresy, belief in more than on God (shirk), and disbelief (kufr).

The extreme teachings of Islamic purification were developed by a preacher named Muhammad Ibn Abd al Wahhab (1703-1792). He stated that the religious practices of Muslims should be in accordance with what had been done by the Prophet and get rid of new religious practices (bid'ab) which he said were dangerous and contrary to the teachings of monotheists in Islam. Among the heresy he mentioned was glorifying religious figures (guardians or Imams), also beautifying and visiting their graves. Ibn Abd al Wahhab then allied with the leader of one of the Arab tribes in the region of Diriyah named Muhammad bin Saud. In 1744 both made an oath to jointly establish a government based on the "principles of true Islam". 37 Then the daughter of Ibn Abd al-Wahhab married the son of

34 Bill Ashcroft, Gareth Griffiths, and Helen Tiffin, Post Colonial Studies: The Key Concepts, 2nd Edition (New York: Routledge, 2007).

35 Greeta Chowdhry and Sheila Nair, Power, Postcolonialism and International Relations: Reading Race, Gender, and Class (London: Routledge, 2002).

${ }^{36}$ Ibid., 12.

${ }^{37}$ R.L Benkin (ed.), What is Moderate Islam? (London: Lexington Books, 2017), 88. 
Muhammad bin Saud. The descendants of this marriage later developed into a number of clans, all of which became pillars supporting the ruling Saudi Dynasty. ${ }^{38}$

Stenslie ${ }^{39}$ identified, there are 4 pillars that support the kingdom of Saudi Arabia, namely the unification of all the clans of the descendants of the Bani Saud, the legitimacy of power from Wahhabi clerics, oil wealth, and security guarantees from the United States of America. This 4th pillar is a continuation of Western imperialist domination in the Middle East. The power of the Saud Dynasty over the territory of the Kingdom of Saudi Arabia (proclaimed in 1932) cannot be separated from British interference. In order to defeat the Ottoman Dynasty, the British requested the assistance of Ibn Saud and through the agreement of the two parties in 1915, the Ikhwan forces loyal to Ibn Saud received financial assistance, weapons, and military training from the British. Personally, Ibn Saud also received a prize of 20,000 pounds and 1,000 rifles. In 1916, another agreement was agreed upon in which the British provided a monthly subsidy of 5,000 pounds, 3,000 rifles and ammunitions, with the promise that Ibn Saud would recruit 4,000 fighters to fight the Ottomans. ${ }^{40}$ In addition, Britain as the dominant power in the Middle East at that time was instrumental in establishing the territorial boundaries of the Saud Dynasty with its neighbors. ${ }^{41}$ After the discovery of oil reserves in the 1930s, the United States replaces Britain as the closest ally of the Saud Dynasty because it is heavily involved in oil exploration in Saudi Arabia. The Saudis then used their enormous oil wealth to spread Wahhabi teachings throughout the world. ${ }^{42}$

In 1979, when US and British domination in Iran collapsed along with the victory of the Islamic Revolution of Iran, Saudi Arabia became an extension of the West in suppressing a new government in Iran. The Saudis spread a narrative accusing the Iranian revolution of

\footnotetext{
38 Panji Haryadi, "The Role of Muhammad bin Salman in the Changes of Saudi Arabia's Pillar of State". Jurnal ICMES: The Journal of Middle East Studies, Vol. 2, No. 1 (Juni 2018): 25-47 [https://doi.org/10.35748/jurnalicmes.v2i1.16]

39 Stig Stenslie, "The End of Elite Unity and the Stability of Saudi Arabia". The Washington Quarterly, [https://doi.org/10.1080/0163660X.2018.1445360] Spring, 2018

${ }^{40}$ Benkin, What is Moderate Islam?, 88.

${ }^{41}$ Shafi Aldamer, Saudi British Relations, $1939-1953$ (Durham: theses of Durham University, 2001).

42 Abdo, The New Sectarianism, 47.
} 
being a Shiite revolution that endangered Sunni-majority countries, along with Wahhabi-based narratives related to Shia's "heres"“. Since then anti-Shia attitudes have grown in the Muslim world and SunniShia harmony has been disturbed. ${ }^{43}$

Saudi Arabia also assisted the US in defeating its rival, the Soviet Union, which occupied Afghanistan (1979-1989). The US and Saudi money played a major role in supporting the Afghan mujahidin militias that were forged with Wahhabi doctrine, and eventually expanded into an Al Qaeda militant movement that spread throughout the world. ${ }^{44}$ Since 2001, the US has turned to fight $\mathrm{Al}$ Qaeda and waged wars in various Muslim countries on the grounds of fighting Al Qaeda terrorism. Al Qaeda then transformed into various other 'jihadist' groups, including ISIS that has carried out acts of terror in various parts of the world, especially in the Middle East.

Some parties, including the European Parliament, ${ }^{45}$ have openly stated that the ideological root of terror groups is the Wahhabi ideology. In 2016, around 200 prominent Sunni scholars (including the Grand Mufti of Egypt, Dr. Ahmed al-Tayyeb) gathered in Grozny, the Chechen Republic, which stated that hardliners who had been involved in extremism and terrorism are not part of AblusSunnab wal Jamaah. In the final communique of the conference, Wahhabi and Salafi were not included in the Ablus-Sunnah community, and conversely, Sufis, Ash'ari, and Maturidi (which according to Wahhabi groups were heretics) were actually categorized as Ablus-Sunnah. ${ }^{46}$

Responding to Grozny conference, Saudi Arabia through mass media and social media strongly condemned the gathering. The attack was mainly aimed at Egyptian ulama' which was considered betraying Saudi which had been providing financial assistance to them. Among other things, Muhammad Al Shaykh, a descendant of Abd al Wahhab

\footnotetext{
${ }^{43}$ Hashemi, "Toward a Political Theory of Sectarianism."

${ }^{44}$ Ibid.

45 Karen Amstrong, "Wahhabism to ISIS: how Saudi Arabia exported the main source of global terrorism", in https://www.newstatesman.com/worldaffairs/2014/11/wahhabism-isis-how-saudi-arabia-exported-main-source-globalterrorism / 27 November 2014 (accessed, September 5, 2019).

46 Abbas Kadhim, "The Sunni Conference In Grozny: A Muslim Intra-Sectarian Struggle For Legitimacy,” https://www.huffpost.com/entry/the-sunni-conferenceat-grozny-muslim-intra-sectarian_b_57d2fa63e4b0f831f7071c1a /18 September 2016/ (accessed, September 4, 2019).
} 
wrote on his Twitter, "Sheikh Al Azhar's participation in a conference in Grozny that expelled Saudi Arabia from the Ablus Sunnah group made us change our policy towards Egypt, because our country is more important, and let Egypt be destroyed." Former Imam of the Grand Mosque (Masjidil Haram), Shaykh Al Kalbani also stated on his Twitter, "The conference in Chechnya shows that the mouths we feed bite us, but we [the Saudi kingdom] don't take lessons." ${ }^{77}$

In the perspective of postcolonialism, such statements, as well as the Saudi track record of pouring huge amounts of money into the project of Wahhabism throughout the world, show evidence that power plays an important role in the production of knowledge. Many groups of scholars, such as the scholars who gathered in Grozny, has carried out the effort to fight the knowledge created by the Wahhabi groups and the Kingdom of Saud, which from the beginning cooperated with Britain. Unfortunately, the effort has not achieved much success because of the lack of power and resources (financial, media control). For example, the Grozny conference was not widely covered by the media so its effect on public opinion was unessential. Another case, in 2017, the British Prime Minister decided not to release the results of an investigation report on the donor country to extreme groups in the United Kingdom. The Prime Minister stated that the nondisclosure of the results of the investigation was for the sake of British national security. The British public criticized this decision and strongly suspected that the country supplying the funds was Saudi Arabia, which is a close ally of the United Kingdom and one of the main buyers of British-made weapons. ${ }^{48}$ This case shows that the power of the British has a significant role in maintaining the sectarian knowledge of Wahhabi in order to continue to dominate the Muslim world.

\section{Conclusion}

Bid'ah is a very sensitive issue and not yet solid in terms of scientific definitions, because there are still many disagreements among scholars regarding this issue. This fact should make Muslims

\footnotetext{
47 Ibid.

48 Caroline Mortimer, "Theresa May still refuses to publish report on Saudi Arabia funding of UK extremists" in https://www.independent.co.uk/news/uk/politics/theresa-may-foreign-terrorfunding-report-uk-extremists-saudi-arabia-isis-security-intelligence-a 7822121.html, 4 July 2017, (accessed, September 4, 2019).
} 
cautious in using bid'ah diction in interacting with fellow Muslims, because bid'ah accusations themselves can actually be categorized as examples of bid'ah behavior. On the other hand, the issue of bid'ab is prone to be used as one of the instruments of division, and this means that the bid'ah issue is very vulnerable to be used as a political instrument for those who want to weaken Muslims, especially Western countries. In the perspective of postcolonialism, the Western powers have always wanted to continue their domination in their former colonies.

History shows how the West plays important roles in shaping and funding, and in collaboration with groups within the Islamic religion that carry out acts of violence against those who are judged to be heresy, shirk, and disbelief. The collaboration between Western powers and these groups continue also seen in the political upheaval that has plagued several countries in the Middle East region, which is known as the Arab Spring. In this catastrophe of the Islamic countries, bid'ab is used as one of the instruments of sectarianism. []

\section{References}

Abdo, Geneve. The New Sectarianism: The Arab Uprisings and The Rebirth of The Shi'a-Sunni Divide. New York: Oxford University Press, 2017.

Aldamer, Shafi. “Saudi British Relations, 1939-1953.” Durham: theses of Durham University, 2001.

Amstrong, Karen. "Wahhabism to ISIS: how Saudi Arabia exported the main source of global terrorism", in https://www.newstatesman.com/world-

affairs/2014/11/wahhabism-isis-how-saudi-arabia-exportedmain-source-global-terrorism, 27 November 2014.

Ashcroft, Bill, Gareth Griffiths, and Helen Tiffin. Post Colonial Studies: The Key Concepts, 2nd Edition. New York: Routledge, 2007.

Asqalani Al, Ibnu Hajar. Fath Al-Bari, Syarh Al-Bukhari. Kairo: Mustafa Al-Bab Al-Habi, 1959.

Benkin, R.L. (ed.). What is Moderate Islam?. London: Lexington Books, 2017.

Callimachi, Rukmini. "To the World, They Are Muslims. To ISIS, Sufis Are Heretics" in https://www.nytimes.com/2017/11/25/world/middleeast/suf i-muslims-isis-sinai.html, 25 November 2017. 
Chowdhry, Geeta and Sheila Nair. Power, Postcolonialism and International Relations: Reading Race, Gender, and Class. London: Routledge, 2002.

Haryadi, Panji. "Peran Mubammad bin Salman dalam Perubahan Pilar Negara Saudi Arabia”. Jumal ICMES, Vol. 2, No. 1 (Juni 2018). [https://doi.org/10.35748/jurnalicmes.v2i1.16]

Hashemi, Nader. "Toward a Political Theory of Sectarianism in the Middle East: The Salience of Authoritarianism over Theology." https:/ /www.mei.edu/publications/toward-political-theorysectarianism-middle-east-salience-authoritarianism-over\#_ftn7, (27 October 2015)

Hurd, Elizabeth Shakman. "Politics of Sectarianism: Retbinking Religion and Politics in The Middle East." Middle East Law and Governance. Vol. 7. [DOI 10.1163/18763375-00701001, 2013$]$

Isa, Mohamad Shafawi Bin Md. Konsep Bid'ah Menurut Imam Nawawi Dan Syekh Abdul Ariz Bin Ba\%. Aceh: thesis of the Faculty of Syari'a dan Law, State Islamic University of Ar-Raniry, 2018.

Kadhim, Abbas. "The Sunni Conference In Grozny: A Muslim IntraSectarian Struggle For Legitimacy." https://www.huffpost.com/entry/the-sunni-conference-atgrozny-muslim-intra-sectarian_b_57d2fa63e4b0f831f7071c1a, 18 September 2016. (accessed 4 September 2019).

Kodir, Abdul. "Sejarah Bid'ah: Ashbab Al Hadith dan Dominasi Wacana Islam Autentik Pada Tiga Abad Pertama Hijriyah." Wawasan: Jurnal Ilmiah Agama dan Sosial Budaya, Vol, 1, No. 2 (July 2016).

Mortimer, Caroline. "Theresa May still refuses to publish report on Saudi Arabia funding of UK extremists." https://www.independent.co.uk/news/uk/politics/theresamay-foreign-terror-funding-report-uk-extremists-saudi-arabiaisis-security-intelligence-a 7822121.html, 4 July 2017. (accessed 4 September 2019)

Muslimi, Farea. "Yemen's Brotherhood: Early Losses and an Unknown Future." https://www.almonitor.com/pulse/fr/originals/2013/09/yemenbrotherhood-losses-unknown-future.html, 25 September 2013. (accessed 4 September 2019) 
Muliono, Slamet, Andi Suwarko, and Zaky Ismail. "Gerakan Salafi Dan Deradikalisasi Islam Di Indonesia." Religió: Jurnal Studi Agama-agama, Vol. 9, No. 2 (September 2019).

Qara'ati, Mohsen. Tafsir-e Noor Jeld-e 9. Qom: Markaz-e Tahqiqat-e Noor, 1999.

Qardhawi, Yusuf. Bid'ah dalam Agama: Hakikat, Sebab, Klasifikasi, dan Pengarubnya. Jakarta: Gema Insani Press, 2014.

Shehabi, Ala'a. "Why Is Bahrain Outsourcing Extremism?" http://www.foreignpolicy.com/articles/2014/10/29/why_is_b ahrain_outsourcing_extremism_isis_democracy, 29 October 2014. (accessed 5 September 2019)

Subhani Al-, Al-Syaikh Ja'far. Al-Bid'ah, Mafhumuba, Hadduba, Atsaruba. Qom: Mu`assasah Al-Imam Al-Shadiq, 1995.

Sukring. "Ideologi, Keyakinan, Doktrin Dan Bid'ah Khawarij: Kajian Teologi Khawarij Zaman Modern.” Jurnal Theologia, Vol. 27, No. 2 (Desember 2016).

Sukron, Mokhamad. "Studi kasus: Memahami Bid'ah dalam Perspektif Majelis Tarjih Alquran (MTA)." Religió: Jurnal Studi Agama-agama, Vol. 5, No. 1 (Maret 2015).

Syathibi, Al-, Abu Ishaq Ibrahim. Al-I'tisham. Beirut: Dar Al-Kutub Al-'Ilmiyah, 2012.

Stenslie, S. "The End of Elite Unity and the Stability of Saudi Arabia." The Washington Quarterly, Spring, (2018). [https://doi.org/10.1080/0163660X.2018.1445360] 